\title{
Peningkatan Minat Dalam Penggunaan Kartu Kredit Syariah dengan Pendekatan Kepercayaan, Sikap dan Pendapatan di Kabupaten Labuhanbatu Utara
}

\author{
Maryam Batubara' ${ }^{1}$ Purnama Ramadani Silalahi' ${ }^{2}$, Audina Rizka Zahra ${ }^{3}$, Rendi \\ Prayoga $^{4}$, Dea Putri Amanda ${ }^{5}$ \\ 12345Universitas Islam Negeri Sumatera Utara \\ purnamaramadani@uinsu.ac.id, audinarizkazahra@gmail.com, \\ rendiprayogaaaa@gmail.com, deaputriamanda0203@gmail.com
}

\begin{abstract}
In non-cash transactions, Islamic credit cards have become a way of life in modern economic culture. The use of Islamic credit cards has risen and fallen throughout time due to a variety of variables. Trust, attitudes, and income are some of these determinants. The goal of this research was to see how beliefs, attitudes, and income affected interest in using Islamic credit cards. The basic data for this study comes from interviews with 38 participants in North Labuhanbatu Regency who were chosen using a borring sample approach. Multiple linear regression was used to evaluate the data. Each trust, attitude, and income level had a favorable and substantial impact on interest in using a sharia credit card, according to the findings. This study benefits (a) academics by providing proof of concept, and (b) Islamic banks by providing data to assess the factors that impact interest in using a sharia credit card.
\end{abstract}

Keywords: Trust, Attitudes, Income, Islamic Credit Cards

\begin{abstract}
ABSTRAK
Dalam transaksi non tunai, kartu kredit syariah telah menjadi gaya hidup dalam budaya ekonomi modern. Penggunaan kartu kredit syariah telah naik turun sepanjang waktu karena berbagai variabel. Keyakinan, sikap, dan pendapatan adalah beberapa faktor penentu ini. Tujuan dari penelitian ini adalah untuk melihat bagaimana keyakinan, sikap, dan pendapatan mempengaruhi minat menggunakan kartu kredit syariah. Data dasar penelitian ini berasal dari wawancara dengan 38 partisipan di Kabupaten Labuhanbatu Utara yang dipilih dengan menggunakan pendekatan borring sample. Regresi linier berganda digunakan untuk mengevaluasi data. Masing-masing kepercayaan, sikap, dan tingkat pendapatan memiliki dampak yang menguntungkan dan substansial terhadap minat menggunakan kartu kredit syariah, menurut temuan tersebut. Penelitian ini bermanfaat bagi (a) akademisi dengan memberikan bukti konsep, dan (b) bank syariah dengan menyediakan data untuk menilai faktor-faktor yang mempengaruhi minat menggunakan kartu kredit syariah.
\end{abstract}

Kata Kunci: Kepercayaan, Sikap, Pendapatan, Kartu Kredit Syariah

PENDAHULUAN 


\section{VISA: Journal of Visions and Ideas \\ Vol 1 No 2 (2022) 207-221 E-ISSN 2809-2058 P-ISSN 2809-2643 \\ DOI: $47467 /$ visa.v1i2.934}

Kegiatan ekonomi berbasis digital merupakan hasil dari kemajuan teknologi. Pada Agustus 2014, Bank Indonesia meluncurkan inisiatif Gerakan Nasional Non Tunai (GNNT) untuk merespons hal tersebut. Gerakan ini mencoba mengubah kebiasaan masyarakat menggunakan uang tunai dan mendorong mereka untuk menggunakan metode non-moneter dalam semua transaksi ekonomi. Jenis perubahan dalam industri perbankan harus dibantu dengan pengenalan barang-barang pendukung. Fasilitas kartu kredit merupakan salah satu produk keuangan yang terkait dengan GNTT.

Publik tidak serta merta menanggapi GNNT. Jumlah uang tunai yang beredar di masyarakat masih Rp 526,6 triliun, menurut angka sejak November 2015. Sementara pengguna kartu kredit hanya 23.070.720. Pada Desember 2015, transaksi tunai mencapai Rp 586,8 triliun, sedangkan transaksi kartu kredit mencapai Rp 26.576.810. Transaksi tunai mencapai Rp528,5 triliun pada Januari 2016, sedangkan pembelian kartu kredit sebesar Rp22.927.128. (bi.go.id).

Dalam statistik di atas, jumlah kartu kredit yang beredar masih didominasi oleh bank tradisional sebagai penyedia layanan tersebut. Bank syariah, seperti sektor perbankan lainnya, lambat merespon produk kartu kredit ini. Hanya satu bank syariah, Bank BNI Syariah, dari 22 bank yang menyediakan kartu kredit syariah hingga 2016.

Jumlah kartu kredit syariah yang diterbitkan oleh BNI syariah meningkat setiap periodenya, karena merupakan satu-satunya bank syariah yang melakukannya. Menurut sumber berita Antaranews.com, jumlah kartu kredit syariah yang diterbitkan pada tahun 2013 melampaui 50.000 pada akhir 2012. Jumlah tersebut meningkat menjadi 92.000 kartu pada pertengahan Juni 2013, melebihi target 90.000 kartu untuk periode tersebut. Berdasarkan laporan Kontan.co.id tahun yang sama, konsumen BNI Hasanah Card hingga Agustus lalu berjumlah 119.732 orang.

Jumlah pengguna kartu kredit syariah pada tahun 2020 mencapai 350.000 pengguna, namun kenaikan ini tidak sebesar kartu kredit Bank BNI biasa(Ulya 2020). Bisnis kartu kredit syariah BNI berkembang, meski tidak secepat induk perusahaannya, Bank BNI. Menurut m.bisnis.com, 1,86 juta kartu kredit BNI telah diberikan pada November 2019, dan angka ini diperkirakan akan meningkat pada tahun 2020, ketika bisnis berencana untuk mendistribusikan tambahan 400.000 kartu kredit (Nurcaya 2020).

Minimnya penggunaan kartu kredit syariah dapat dikaitkan dengan sejumlah penyebab. Satu masalah, menurut beberapa pihak berwenang, adalah bahwa masyarakat umum tidak menyadari bahwa kartu kredit Islami ada. Bank syariah menghadapi tugas yang sulit dalam mendorong konsumen untuk menggunakan kartu kredit syariah. Menurut berbagai penelitian, berbagai faktor dapat mempengaruhi keinginan seseorang untuk menggunakan kartu kredit. Keyakinan, sikap, dan pendapatan hanyalah beberapa di antaranya. 


\section{VISA: Journal of Visions and Ideas \\ Vol 1 No 2 (2022) 207-221 E-ISSN 2809-2058 P-ISSN 2809-2643 \\ DOI: 47467/visa.v1i2.934}

Kepercayaan nasabah, menurut Jamshidi dan Rezai, merupakan salah satu unsur yang berkontribusi terhadap peningkatan penggunaan kartu kredit syariah. Sudut pandang ini didukung oleh hasil Ardiyani, yang menurutnya kepercayaan memiliki dampak besar pada minat. Variabel lain yang mempengaruhi minat pelanggan, seperti variabel sikap, diteliti oleh Jamshidi dan Rezai dalam penelitian yang sama. Pandangan konsumen memiliki pengaruh menguntungkan yang kuat terhadap minat menggunakan kartu kredit syariah, menurut temuan penelitian ini. Faktor terakhir, pendapatan, berdampak pada suku bunga. Hal ini sejalan dengan hasil penelitian Mansor dan Mat yang menyatakan bahwa uang memiliki pengaruh yang cukup besar terhadap penggunaan kartu kredit syariah (Mansor and Che-Mat 2009). Ardiyani menemukan hal yang sama, yaitu pendapatan berpengaruh positif dan substansial terhadap suku bunga.

Telah disebutkan pada uraian sebelumnya bahwa ada berbagai alasan yang mempengaruhi keinginan seseorang untuk menggunakan fasilitas kartu kredit syariah. Aspek kepercayaan, sikap, dan pendapatan klien menjadi pokok bahasan penelitian ini, yang didasarkan pada teori. Karena kendala dalam menilai kemampuan peneliti, penelitian ini hanya memasukkan tanggapan dari masyarakat di Kabupaten Labuhanbatu Utara.

\section{Minat Penggunaan Kartu Kredit Syariah}

KBBI mendefinisikan minat sebagai keinginan yang kuat terhadap sesuatu. Untuk menikmati sesuatu, seseorang harus mengolahnya baik di dalam maupun di luar. Rasa ingin tahu bisa saja terjadi pada saat yang bersamaan, menurut Prof. Dr. Iskandarwasid dan Dr. H. Dadang Sunendar. Pilihan pelanggan dipengaruhi oleh berbagai elemen, salah satunya adalah tingkat minat mereka. Yang pertama adalah sikap yang memiliki kemampuan untuk secara selektif memfokuskan perhatian seseorang. Kedua, persepsi orang tentang betapa pentingnya aktivitas dan hobi tertentu bagi mereka. Ketiga, sebagai bagian dari motivasi atau persiapan tindakan yang mengarah pada tujuan atau arah tertentu (Rachmawati 2017).

Salah satu komponen pikiran manusia yang dapat memotivasi orang untuk mencapai tujuan mereka adalah minat mereka. Seseorang yang tertarik pada sesuatu cenderung lebih memperhatikan atau lebih menikmatinya (Kusumah 2009).Dorongan untuk terus menggunakan suatu hal dikenal dengan minat penggunaan (Ari 2013). Ketika seseorang mengevaluasi sesuatu yang berharga baginya, dia cenderung ingin menggunakannya lagi dan merasa puas. Minat adalah kekuatan pendorong yang menyebabkan kita tertarik atau merasa tertarik pada orang, objek, atau aktivitas, atau bisa juga perasaan kuat yang dipicu oleh tindakan itu sendiri.

Menurut pernyataan di atas, seseorang yang terlibat dalam suatu kegiatan tertentu akan memperhatikannya secara teratur karena dimotivasi oleh kepentingannya sendiri daripada faktor eksternal. Dengan kata lain, minat adalah keinginan alami untuk menghargai dan tertarik pada apa pun. Minat menggunakan 


\section{VISA: Journal of Visions and Ideas \\ Vol 1 No 2 (2022) 207-221 E-ISSN 2809-2058 P-ISSN 2809-2643 \\ DOI: 47467/visa.v1i2.934}

kartu kredit didefinisikan sebagai sensasi minat yang disertai perasaan senang saat menggunakan alat pembayaran berupa kartu yang dananya dipinjamkan oleh suatu lembaga di suatu daerah yang pembayarannya dapat dilakukan tanpa harus membayar tunai, menurut perspektif ini.

Ada dua jenis kekuatan yang menghasilkan minat: internal dan eksternal (Shaleh 2009). Dorongan dari dalam individu, alasan sosial, dan penyebab emosional adalah contoh pengaruh internal. Dorongan internal seseorang digambarkan sebagai segala sesuatu yang memotivasi individu untuk memenuhi kebutuhannya sendiri. Kebutuhan ini merupakan dorongan tubuh, motivasi, untuk melindungi diri dari rasa lapar dan rasa ingin tahu. Selanjutnya, motif sosial digambarkan sebagai sesuatu yang menyebabkan perubahan lingkungan atau perilaku untuk memenuhi tuntutan sosial, seperti pekerjaan, mendapatkan prestise, atau menerima hadiah. Emosi adalah komponen internal ketiga. Menurut aspek emosional, keberhasilan dalam tindakan yang didorong oleh keinginan menghasilkan kesenangan dan memperkuat minat saat ini. Kegagalan sebaliknya akan menurunkan keinginan seseorang untuk berhasil. Kedudukan ekonomi, pendidikan, situasional (orang dan lingkungan), dan faktor psikologis merupakan empat aspek variabel eksternal.

Unsur internal dari motivasi individu dan faktor eksternal dari posisi ekonomi merupakan faktor yang menentukan minat dalam penelitian ini. Persepsi, pandangan atau keyakinan, harapan pribadi, keinginan, emosi senang atau tidak puas, dan kepuasan termasuk dalam aspek internal dorongan individu (Sudrajat 2010). Menurut Hurlock, ketika situasi ekonomi masyarakat membaik, mereka cenderung memperluas minat mereka untuk memasukkan hal-hal yang sebelumnya tidak dapat mereka capai. Kepentingan masyarakat cenderung terbatas karena tingkat ekonomi mereka berkurang karena kewajiban keluarga atau perusahaan yang kurang berkembang. Dalam penelitian ini, pendapatan digunakan untuk menentukan status ekonomi.

\section{Pengaruh Kepercayaan Terhadap Minat Penggunaan Kartu Kredit Syariah}

Kepercayaan ialah komponen penting untuk menjalin hubungan keterikatan dengan perusahaan dan pelanggannya. Kepercayaan merupakan kekuatan sebuah produk mempunyai petunjuk serta seluruh wawasan pengguna, serta kesimpulan mereka tentang objek, kualitas, dan keunggulan, semuanya berkontribusi pada Produk tersebut memiliki atribut dan kekuatan manfaat tertentu (Sopiah 2013). Kepercayaan konsumen ialah masalah bagaimana individu memahami kondisi ekonomi (keuangan) konsumen. Kepercayaan bertujuan untuk mengukur keinginan konsumen untuk berbelanja, kemudian mendukung untuk memnaksir keinginan konsumen. Selanjutnya, memahami dampak peristiwa yang mendorong motif belanja.

Kepercayaan bisa dilihat dari kepercayaan konsumen terhadap kemampuan serta fungsionalitas kartu kredit syariah. Setelah diperkenalkannya kartu kredit syariah, karena keyakinan konsumen, penggunaannya akan meningkat (D Jamshidi and Rezaei 2012). Kepercayaan antara pelanggan dan staf penjualan perlu dijaga untuk 


\section{VISA: Journal of Visions and Ideas \\ Vol 1 No 2 (2022) 207-221 E-ISSN 2809-2058 P-ISSN 2809-2643 \\ DOI: 47467/visa.v1i2.934}

menjaga hubungan kepada pelanggan. Situasi ini tentu menumbuhkan keyakinan pelanggan di masa depan sehingga pada hasilnya membangun loyalitas pelanggan. Dengan diperkenalkannya kartu kredit, sebagai kepercayaan konsumen, penggunaan kartu kredit syariah akan meningkat(Dariyoush Jamshidi and Hussin 2012). Dengan cara tersebut dapat diambil kesimpulan yakni semakin tinggi kepercayaan orang tentang kartu kredit syariah sehingga makin besar pula ketertarikan untuk memakai kartu kredit syariah.

Dalam penelitian sebelumnya, hubungan antara variabel keyakinan dan minat konsumen telah ditemukan. Penelitian Ardiyani menyimpulkan Kepercayaan ini memiliki dampak positif yang signifikan terhadap minat. Kepercayaan menyangkut kemauan seorang akan bertindak dengan cara tertentu sebab dia yakin yakin pasangannya akan memberikan kesenangan yang dia inginkan.Seseorang pada umumnya mengharapkan perkataan, janji atau penjelasan orang lain yang bisa dipercaya. pertimbangkan bisa diuji dengan kepercayaan pelanggan dalam keseluruhan kinerja dan fitur kartu kredit syariah.

\section{Pengaruh Sikap Terhadap Minat Pengunaan Kartu Kredit Syariah}

Sikap adalah konsep yang paling krusial untuk mempelajari sikap konsumen. dengan mensugesti perilaku konsumen, pemasar berharap bisa mensugesti sikap pembelian konsumen. perilaku adalah ekspresi emosi, yang mencerminkan perasaan suka atau tidak senang seseorang, suka atau tidak suka, putusan bulat atau tidak setuju kepada objek. perilaku menempatkan sesuatu pada benak konsumen, senang atau tidak senang terhadap sebuah objek, serta apakah konsumen mendekati atau menjauhi objek tadi. perilaku membentuk orang berperilaku relatif konsisten menggunakan objek yang sama. Kemudian, perilaku adalah kombinasi berasal pandangan baru-pandangan baru, mengungkapkan perasaan holistik atau evaluasi pribadi terhadap sesuatu. oleh karena itu, sikap dapat mengakibatkan orang berperilaku sangat konsisten dengan objek yang sama(Muanas 2014).

Sesuai teori model sikap terpola yang dikemukakan oleh Ajzen, dijelaskan bahwa faktor utama yang menghipnotis sikap seorang merupakan Ketertarikan atau kecenderungan untuk melakukannya. dengan mempengaruhi sikap konsumen, konsumen akan merasa suka (tertarik) atau tidak menyukai barang yang ditawarkan. Berdasarkan teori tersebut, penelitian ini menduga bahwa sikap dan minat konsumen dalam menggunakan kartu kredit syariah saling berkaitan. Penelitian yang dilakukan oleh Jamshidi dan Ali membuktikan bahwa ada hubungan antara sikap dan minat konsumen, yaitu sikap memiliki pengaruh yang signifikan pada pemakaian inovasi, produk, serta layanan baru.(D Jamshidi and Rezaei 2012)

\section{Pengaruh Pendapatan Terhadap Minat Penggunaan Kartu Kredit Syariah}

Pendapatan merupakan hasil dari proses aktivitas yang didapat perusahaan ataupun individu, berupa aktivitas jual beli yang ditentukan untuk membuat 


\section{VISA: Journal of Visions and Ideas \\ Vol 1 No 2 (2022) 207-221 E-ISSN 2809-2058 P-ISSN 2809-2643 \\ DOI: $47467 /$ visa.v1i2.934}

perusahaan maupun individu memperoleh keuntungan atau laba (Rahayu and Suhayati 2010). Latar belakang penghasilan yang digunakan pada penelitian ini ialah penghasilan pribadi.Penghasilan pribadi bisa didefinisikan sebagai seluruh jenis penghasilan, termasuk pendapatan yang diperoleh penduduk suatu negara yang tidak melakukan kegiatan apapun selama jangka waktu tertentu. Indikator pendapatan dalam penelitian ini adalah besarnya pendapatan selama 1 bulan. Pendapatan sebulan mengacu pada seluruh total pendapatan yang didapat dari upah atau bonus (Mizan 2014).

Pendapatan ialah salah satu penentu yang paling utama dalam penggunaan kartu kredit. Di sini, mereka percaya bahwa orang-orang dengan penghasilan tinggi lebih tertarik pada kartu kredit dan kebanyakan membayar tagihan tepat waktu (Khalid et al. 2013). Studi yang dilakukan oleh Manshor dan kawan-kawan menunjukkan bahwa pendapatan merupakan faktor penting yang mendorong peningkatan penggunaan kartu kredit. Adiyanti juga mengungkapkan pandangan yang sama bahwa pendapatan yang tinggi akan meningkatkan bunga. Oleh karena itu, ketika seseorang memiliki pendapatan lebih, konsumsi akan meningkat, atau gaya hidup akan meningkat. Dengan cara ini, jika pendapatan tinggi, minat untuk memakai produk baru akan lebih tinggi, dan sebaliknya (Prasanti 2021).

\section{Kerangka Pemikiran}

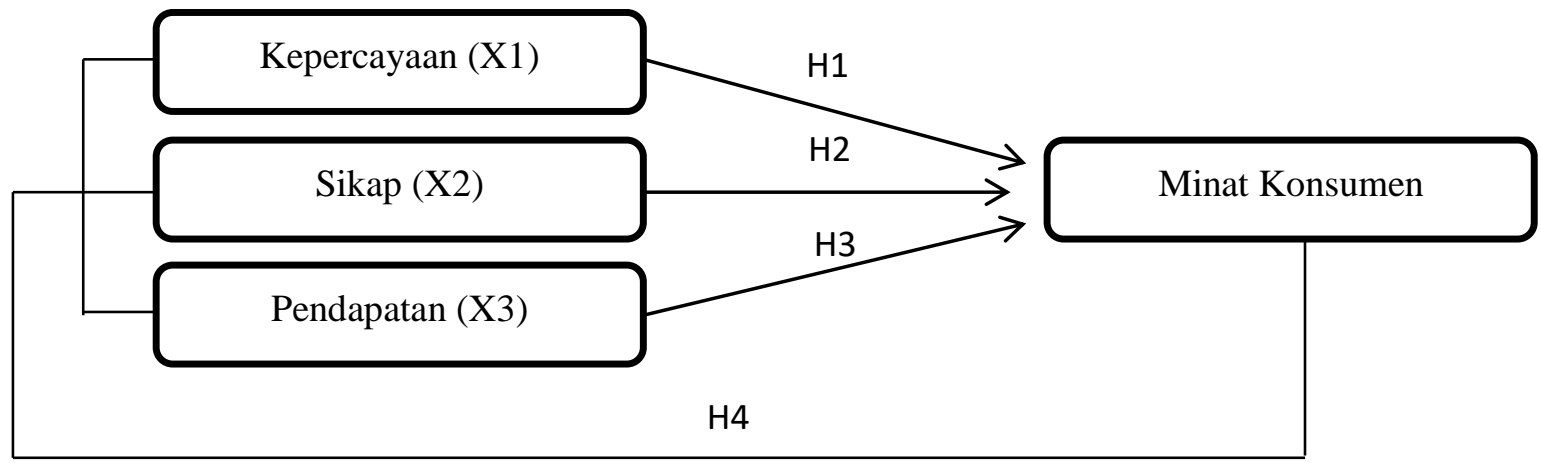

\section{Hipotesis}

$H_{1}$ : Terdapat pengaruh kepercayaan terhadap minat masyarakat dalam penggunaan kartu kredit syariah

$H_{2}$ : Terdapat pengaruh sikap terhadap minat masyarakat dalam penggunaan kartu kredit syariah

$H_{3}$ : Terdapat pengaruh pendapatan terhadap minat masyarakat dalam penggunaan kartu kredit syariah

\section{METODE PENELITIAN}




\section{VISA: Journal of Visions and Ideas \\ Vol 1 No 2 (2022) 207-221 E-ISSN 2809-2058 P-ISSN 2809-2643 \\ DOI: $47467 /$ visa.v1i2.934}

Jenis penilitian kali ini ialah menggunakan penelitian kuantitatif. Total riset ini mencakup beberapa orang yang berjumlah 38 orang yang merupakan masyarakat. Narasumber merupakan beberapa masyarakat di Labuhanbatu Utara tahun 2021. Penelitian kali ini menggunakan data utama yang diperoleh dari kuesioner yang disebarkan (Sopiah 2013). Kuesioner ini berisi data pribadi dari narasumber dan beberapa pernyataan yang berhubungan dengan variabel penelitian. Narasumber menggunakan skala linkert 1 sampai 5 untuk mengisi jawaban mereka. Angka 1 menunjukkan persetujuan yang kuat, angka 2 menunjukkan persetujuan, dan angka 3, 4, dan 5 menunjukkan netralitas, ketidaksetujuan, dan ketidaksetujuan yang kuat. Data pada penelitian ini dianalisis dengan SPSS. 20 Ada 2 sesi. Sesi 1 adalah uji hipotesis klasik, lalu uji regresi linier berganda. Pengujian hipotesis klasik terdiri dari uji normalitas, uji autokorelasi, uji heteroskedastisitas dan uji multikolinearitas. Serta uji regresi linier berganda meliputipenyesuaian $\mathrm{R} 2$, uji F dan pengukuran nilai t signifikan. Operasi variabel dijelaskan sebagai berikut.

\begin{tabular}{|c|c|c|}
\hline Variabel & Definisi & Indikator \\
\hline Kepercayaan & $\begin{array}{l}\text { kepercayaan merupakan kekuatan pada } \\
\text { produk dengan atribut tertentu, yaitu } \\
\text { seluruh wawasan yg dimiliki konsumen, } \\
\text { serta seluruh kesimpulan yang didesain } \\
\text { konsumen perihal objek, atribut, serta } \\
\text { fungsinya. }\end{array}$ & $\begin{array}{ll}\text { - } & \text { Integritas } \\
\text { - } & \text { Kebaikan } \\
\text { - Kemampuan }\end{array}$ \\
\hline Sikap & $\begin{array}{l}\text { Sikap adalah sejenis sistem psikis dan saraf } \\
\text { yang berhubungan dengan persiapan } \\
\text { respon, diorganisasikan melalui wawasan, } \\
\text { dan mempunyai akibat langsung dan tidak } \\
\text { langsung terhadap perilaku. Sikap juga } \\
\text { ialah salah satu konsep terpenting yang } \\
\text { dipakai pemasar untuk mengerti } \\
\text { konsumen. }\end{array}$ & $\begin{array}{ll}\text { - } & \text { Kepercayaan } \\
& \text { terhadap merek } \\
\text { - } & \text { Evaluasi merek } \\
\text { - } & \text { Niat membeli }\end{array}$ \\
\hline Pendapatan & $\begin{array}{l}\text { Pendapatan merupakan sebuah hasil dari } \\
\text { proses aktivitas yang dihasilkan } \\
\text { perusahaan atau individu, yaitu aktivitas } \\
\text { jual beli yg ditentukan untuk membuat } \\
\text { perusahaan atau individu memperoleh } \\
\text { keuntungan atau laba. }\end{array}$ & $\begin{array}{l}\text { - Total } \\
\text { penghasilan } \\
\text { yang didapat } \\
\text { selama } 1 \text { bulan }\end{array}$ \\
\hline $\begin{array}{l}\text { Minat } \\
\text { Penggunaan }\end{array}$ & $\begin{array}{l}\text { Minat Penggunaan ialah kehendak } \\
\text { seseorang untuk terus memakai suatu } \\
\text { barang. }\end{array}$ & 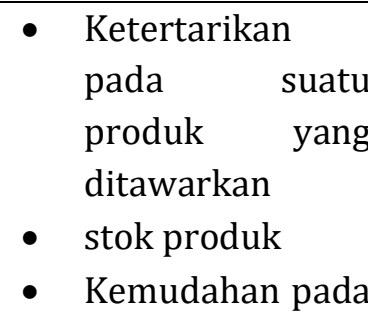 \\
\hline
\end{tabular}


\begin{tabular}{|c|c|c|}
\hline & pembelian \\
\hline
\end{tabular}

\section{HASIL DAN PEMBAHASAN}

\section{Uji Asumsi Klasik}

\subsection{Uji Normalitas}

Mengetes apakah suatu variabel pengacau mempunyai distribusi alami dalam suatu bentuk regresi. Bentuk regresi bagus yaitu model regresi yang terdistribusi alami atau mengarah ke alami merupakan tujuan dari uji normalitas. Metode menemukannya yaitu menatap representasi grafis dari histogram adalah jika histogram sedikit lagi berbentuk lonceng dan semua titik deviasi mencontoh arah diagonal, maka bentuk regresi mengikuti hipotesis alami bahwa itu dapat digunakan.

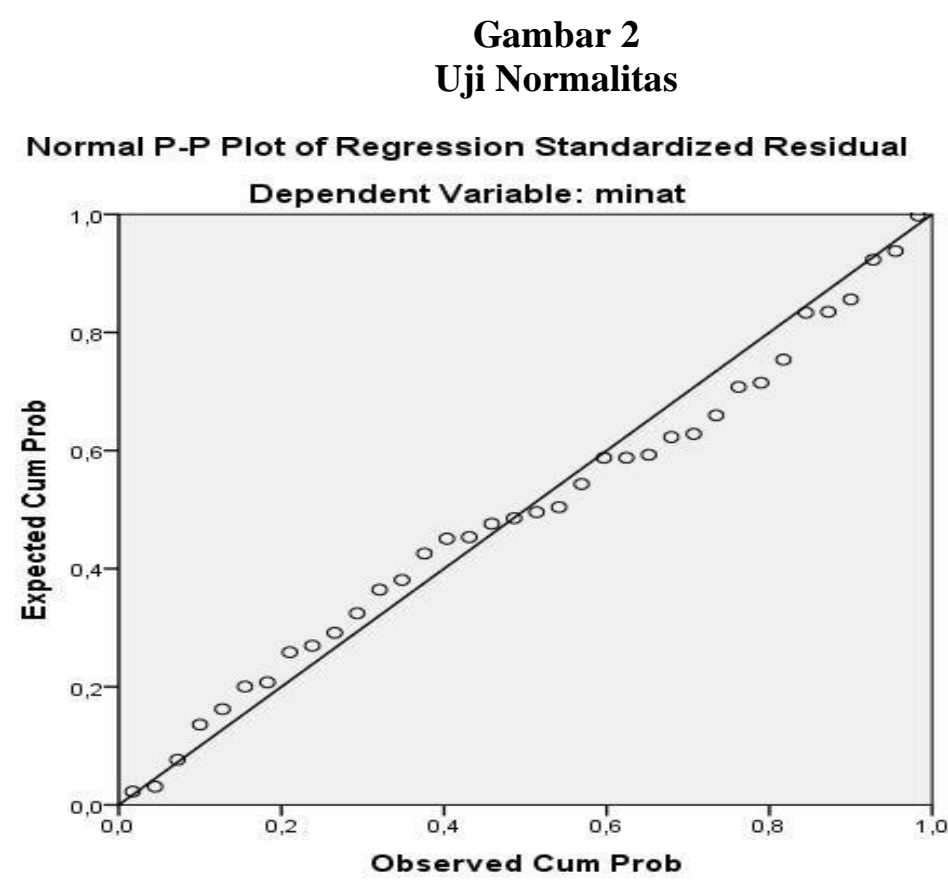

Sumber: Dibuat 2021

Dapat memeriksa data alami dengan menatap histogram dari residual yaitu ketika data menebar sepanjang diagonal dan mencontoh arah diagonal, ataupun jika histogram plot membuktikan desain distribusi alami, maka bentuk regresi mempadati hipotesis alami. Jika Gambar 2 dilihat, kita bisa menyimpulkan bahwasanya data tersebut alami. Hal ini dianggap alami dikarenakan data menebar sepanjang diagonal dan mencontoh arah diagonal yang mewakili desain distribusi alami.

\subsection{Uji Autokorelasi}

Memahami apa adakah korelasi dalam bentuk regresi linier diantara kelalaian 


\section{VISA: Journal of Visions and Ideas \\ Vol 1 No 2 (2022) 207-221 E-ISSN 2809-2058 P-ISSN 2809-2643 \\ DOI: $47467 /$ visa.v1i2.934}

campuran dalam periode t dan kelalaian campuran dalam t-1 (terdahulu) merupakan tujuan dari uji autokorelasi. Dari antara yang ada untuk menemukan apakah ada autokorelasi adalah dengan melaksanakan DW Test yang artinya Durbin-Watson. Adapun standard ketentuan dengan memakai dL dan dU dari tabel DW Test untuk melakukan uji autokorelasi, ada bermacan tindakan untuk melakukan keputusan apakah autokorelasi dengan DW Test dilakukan dalam kondisi berikut:

a) Jikalau nilai DW kurang dari -2, terjadi autokorelasi positif, dan

b) Jikalau nilai DW antara -2 dan 2 atau $-2 \leq 2$, tidak terjadi autokorelasi.

c) Jikalau Autokorelasi negatif terjadi ketika nilai DW 2/DW $>2$.

Dari Tabel 3 di bawah, kami memperoleh nilai DW 1,745 dalam analisis regresi kami. DW menunjukkan bahwasanya DW adalah antara -2 dan 2 . Oleh karena itu, bisa diambil kesimpulan bahwa autokorelasi tidak ada pada penelitian ini.

\section{Tabel 3}

Hasil Uji Autokorelasi

\begin{tabular}{|c|c|c|c|c|c|}
\hline \multicolumn{5}{|c|}{ Change Statistics } & \multirow{2}{*}{$\begin{array}{l}\text { Durbin-Wat } \\
\text { son }\end{array}$} \\
\hline $\begin{array}{l}\text { R Square } \\
\text { Change }\end{array}$ & F Change & df1 & df2 & Sig F Change & \\
\hline 666 & 21,306 & 3 & 32 & 000 & 1,745 \\
\hline
\end{tabular}

a. Predictors: (Constant), pendapatan, kepercayaan, sikap

b. Dependent Variable: minat

Sumber: Dibuat 2021

\subsection{Uji Heteroskedastisitas}

Agar bisa memahami apakah versi residual satu pengamatan dalam suatu model regresi sesuai dalam penglihatan lainnya merupakan tujuan dari uji heteroskedastistas. Jika versi residual dari satu penglihatan ke penglihatan lainnya sungguh-sungguh, dikatakan versi sama, jika tidak, dikatakan heteroskedastis. Bentuk regresi yang bagus adalah bentuk regresi dengan atau tanpa heteroskedastisitas.

Step memperkirakan apakah ada heteroskedastisitas dalam sebuah gaya bisa diamati pada scatterplot gaya tersebut. Menganalisis ilustrasi scatterplot yang mengungkapkan bahwa tidak ada heteroskedastisitas dalam gaya regresi linier berganda jikalau titik-titik data tersebar di atas atau di bawah atau mendekati nol dan titik-titik data tidak terkumpul hanya di atas atau di bawah (Ghozali 2011)

Gambar 3

Hasil Uji Heteroskedastisitas 


\section{VISA: Journal of Visions and Ideas \\ Vol 1 No 2 (2022) 207-221 E-ISSN 2809-2058 P-ISSN 2809-2643 \\ DOI: $47467 /$ visa.v1i2.934}

Pada Gambar 3, Anda bisa melihat skala plot titik data tersebut atau di bawah nol atau mendekati nol. Oleh karena itu, bisa diambil kesimpulan bahwasanya tidak melakukan heteroskedastisitas pada gaya regresi.

\subsection{Uji Multikolinearitas}

Bersumber Ghozali, multikolinearitas bisa kita lihat pada nilai Tolerance dan relative Variance Inflation Factor (VIF) (Ghozali 2011). Pada skala ini mewakili setiap variabel independen yang dipaparkan oleh variabel independen lainnya. Nilai cutoff yang umum digunakan untuk memperkirakan tidak adanva tanda-tanda multikolinearitas :Sumber: Dibuat 2021

Sumber: Dibuat 2021

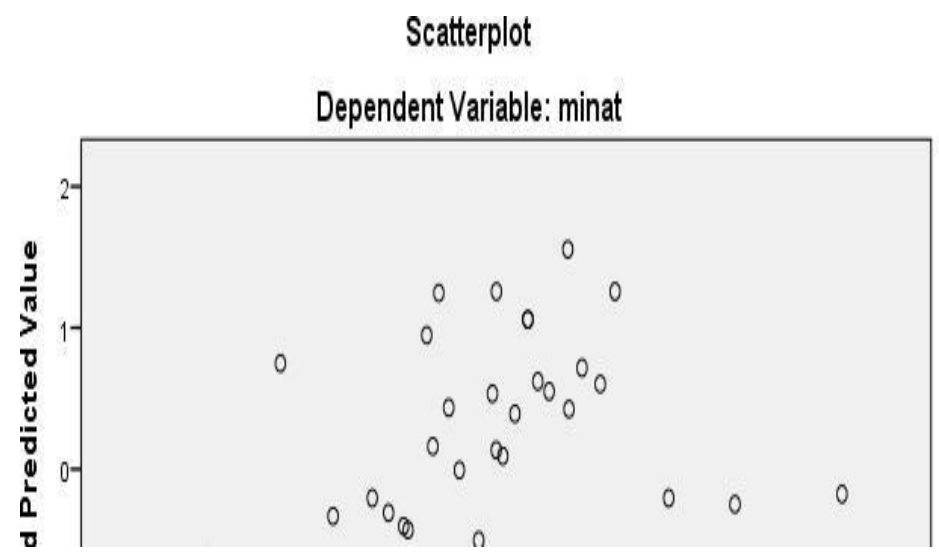




\section{VISA: Journal of Visions and Ideas \\ Vol 1 No 2 (2022) 207-221 E-ISSN 2809-2058 P-ISSN 2809-2643 \\ DOI: 47467/visa.v1i2.934}

Tabel 4

Hasil Uji Multikolinearitas

Coefficients $^{\mathrm{a}}$

\begin{tabular}{|r|r|r|r|r|}
\hline \multicolumn{3}{|c|}{ Correlations } & \multicolumn{2}{|c|}{ Collinearity Statistics } \\
\hline Zero-order & \multicolumn{1}{|c|}{ Partial } & \multicolumn{1}{c|}{ Part } & \multicolumn{1}{|c|}{ Tolerance } & \multicolumn{1}{|c|}{ VIF } \\
\hline, 769 &, 539 &, 369 &, 526 & 1,902 \\
, 711 &, 375 &, 234 &, 501 & 1,997 \\
, 514 &, 109 &, 063 &, 669 & 1,495 \\
\hline
\end{tabular}

a. Dependent Variable: minat

Sumber: Dibuat 2021

Pada Tabel 4 ditemukan bahwasanya variabel tingkat inflasi (VIF) kurang dari 10 dan toleransi bertambah banyak dari 0,1. Oleh begitu bisa diambil kesimpulan bahwasanya tidak terdapat multikolinearitas antara variabel bebas keyakinan, sikap, dan pendapatan bunga.

\section{Uji Ketepatan}

\subsection{Model Uji F}

Efek uji $\mathrm{F}$ bisa dikonfirmasi dari nilai $\mathrm{F}_{\text {hitung }}$ pada Tabel 5 yang ditemukan dengan nilai probabilitas $F_{\text {hitung }} 21.306$ dan 0,000, dan hasil ini diperoleh dengan membandingkan hasil dengan $\mathrm{F}_{\text {tabel }}$ (dari df 3; dihitung menggunakan Microsoft Excel pada 32 dan $=0,05$ ). nilai $F_{\text {tabel }}=5,172$ ). Oleh karena itu, jika $F_{\text {hitung }}>F_{\text {tabel }}$ dan nilai probabilitasnya bertambah kecil dari $=0,05$ menunjukkan bahwa parameter gaya akurat dan bisa digunakan untuk memperkirakan variabel terikat. Oleh sebab itu, bisa diambil kesimpulan bahwasanya keyakinan, sikap, dan pendapatan layak digunakan sebagai gaya regresi dan bisa dimanfaatkan untuk memperkirakan ketertarikan penoounaan kartu kredit crariah

Tabel 5

Hasil Uji F

\begin{tabular}{|rl|r|r|r|r|r|}
\hline Model & \multicolumn{1}{c|}{$\begin{array}{c}\text { Sum of } \\
\text { Squares }\end{array}$} & \multicolumn{1}{c|}{ df } & \multicolumn{1}{c|}{$\begin{array}{c}\text { Mean } \\
\text { Square }\end{array}$} & F & Sig. \\
\hline \multirow{2}{*}{1} & Regression & 250,707 & 3 & 83,569 & 21,306 &, $000^{\mathrm{b}}$ \\
& Residual & 125,515 & 32 & 3,922 & & \\
\hline & Total & 376,222 & 35 & & & \\
\hline
\end{tabular}

Sumber: Dibuat 2021

2Sumber: Diolah 2021

Antara 0 dan 1 merupakan koefesien dari determinasi. Bergantung pada hasil perhitungan, kami mendapatkan angka kuadrat yang dikoreksi $\mathrm{R}=0,635$ atau 63,5\%. 


\section{VISA: Journal of Visions and Ideas \\ Vol 1 No 2 (2022) 207-221 E-ISSN 2809-2058 P-ISSN 2809-2643 \\ DOI: 47467/visa.v1i2.934}

Artinya kemahiran menjelaskan persentase dimana variabel penjelas seperti keyakinan, sikap, dan pendapatan sebagai variabel terikat adalah $63,5 \%$, dan sisanya $36,5 \%$ terkena pengaruh oleh variabel yang lain dari model yang tidak diteliti dalam penelitian ini.

Tabel 6

Hasil Uji Koefisien Determinasi $\left(R^{2}\right)$

Hasil Uji Koefisien Determinasi

\begin{tabular}{|l|c|c|c|r|}
\hline Model & $\mathrm{R}$ & R Square & $\begin{array}{c}\text { Adjusted } R \\
\text { Square }\end{array}$ & Std. Error of the Estimate \\
\hline 1 &, $816^{\mathrm{a}}$ &, 666 &, 635 & 1,980 \\
\hline
\end{tabular}

Sumber: Diolah 2021

\subsection{Uji Regresi Linier Berganda}

Persamaan regresi diperoleh berdasarkan hasil regresi berganda. Artinya, $Y=3,082+0,461_{x 1}+0,344_{x 2}+$ Persamaan ini diinterpretasikan menjadi:

1. Nilai konstan positif 3,082 berarti tingkat bunga penggunaan kartu kredit syariah adalah 3,082 jika variabel keyakinan, hubungan, dan pendapatan dipertahankan konstan.

2. Koefisien regresi untuk variabel keyakinan (x1) adalah positif dan sama dengan 0,461 . Artinya variabel hubungan dan pendapatan dianggap konstan dan nilai persentasenya meningkat sebesar 0,461 untuk setiap kenaikan 1 satuan kepercayaan.

3. Koefisien regresi variabel rasio (x2) bernilai positif sebesar 0,344. Artinya kenaikan rasio sebesar satu satuan meningkatkan persentase sebesar 0,344, mengingat variabel kepercayaan dan pendapatan tetap konstan.

4. Koefisien regresi (x3) untuk variabel pendapatan adalah positif dan sama dengan 0,167. Artinya, untuk setiap kenaikan 1 unit pendapatan, nilai persentasenya meningkat sebanyak 0,167, dengan asumsi variabel keyakinan dan sikap benar-benar konstan.

\subsection{Uji Signifikansi (Uji t)}

Pada Tabel 7 dapat dilihat bahwasanya variabel confidence ditemukan dengan nilai $t_{\text {hitung }}=3,619$ dan probabilitas 0,001 . $t_{\text {hitung }}>t_{\text {tabel }}$ dan nilai $<0 t_{\text {hitung }}=$ $2,287>t_{\text {tabel }}$ dan nilai $<0$ xss $=$ dihilangkan $>$ ttabel dan nilai \& lt; dibandingkan dengan $t_{\text {tabel }}(2,037) 0,05$. Perihal hal tersebut memperlihatkan bahwa $\mathrm{H}_{0}$ bias. Perihal hal tersebut bermakna adanya pengaruh yang baik dan penting antara pendapatan dan bunga. 


\section{VISA: Journal of Visions and Ideas \\ Vol 1 No 2 (2022) 207-221 E-ISSN 2809-2058 P-ISSN 2809-2643 \\ DOI: 47467/visa.v1i2.934}

Variabel rasio yang dihasilkan adalah thitung $=2,287$ dan probabilitasnya 0,029. $t_{\text {hitung }}>t_{\text {tabel }}$ dan nilai \& lt; bila dibandingkan dengan $t_{\text {tabel }}(2.037) 0,05$. Perihal hal tersebut memperlihatkan bahwa $\mathrm{H}_{0}$ bias. Bermakna sikap terhadap minat berpengaruh positif dan signifikan. Nilai variabel pendapatan adalah $\mathrm{t}_{\text {hitung }}=$ 2,121 dan probabilitasnya 0,039 , jikalau $t_{\text {tabel }}(2,037)$ berarti $t_{\text {hitung }}>t_{\text {tabel }} \&$ lt; 0,05 . Perihal hal tersebut memperlihatkan bahwasanya $\mathrm{H}_{0}$ bias. Perihal hal tersebut pasti adanya pengaruh yang positif dan penting antara penghasilan dan bunga.

\begin{tabular}{|l|c|c|l|}
\hline Variabel & thitung $_{\text {Kepercayaan }}$ & Sig. & \multicolumn{1}{c|}{ Kesimpulan } \\
\hline Sikap & 3,619 & 0,001 & $\begin{array}{l}\text { Adanya dampak yang positif serta } \\
\text { signifikan antara kepercayaan terhadap } \\
\text { minat. }\end{array}$ \\
\hline Pendapatan & 2,287 & 0,029 & $\begin{array}{l}\text { Adanya dampak yang positif serta } \\
\text { signifikan antara sikap terhadap minat. }\end{array}$ \\
\hline
\end{tabular}

Sumber: Diolah 2021

\section{KESIMPULAN}

Berlandaskan hasil analisis serta pembahasan, maka jawaban dari rumusan masalah dapat ditarik kesimpulan sebagai berikut :

a. Kepercayaan berdampak positif serta signifikan tentang minat menggunakan kartu kredit syariah. Situasi ini dibuktikan oleh nilai probabilitas $0,001<\alpha 0,05$ serta nilai koefisiennya 0,461 . keterangan lain menunjukkan nilai $t_{\text {hitung }}=3,619$ serta probabilitas sebesar 0,001 , bila dibandingkan dengan $t_{\text {tabel }}=2,287$ maka $t_{\text {hitung }}>t_{\text {tabel }}$ dan $P_{\text {value }}<0,05$.

b. Sikap berdampak positif serta signifikan tentang minat menggunakan kartu kredit syariah. Situasi ini dibuktikan oleh nilai probabilitas signifikan $0,029<\alpha 0,05$ serta nilai koefisiennya 0,344 . keterangan lain didapat nilai $t_{\text {hitung }}=2,287$ serta probabilitas sebesar 0,029, jika dibandingkan dengan $t_{\text {tabel }}=2,037$ maka $t_{\text {hitung }}>t_{\text {tabel }}$ dan $P_{\text {value }}<0,05$.

c. Pendapatan berdampak positif serta signifikan tentang penggunaan kartu kredit syariah. Situasi ini dibuktikan oleh nilai probabilitas signifikan $0,039<\alpha 0,05$ serta nilai koefisiennya0,167. Indikator lain menunjukkan bahwa nilai $t_{\text {hitung }}=2,121$ serta probabilitas sebesar0,039, bila dibandingkan dengan $t_{\text {tabel }}=2,037$ maka $t_{\text {hitung }}>t_{\text {tabel }}$ serta $P_{\text {value }}<0,05$. 


\section{VISA: Journal of Visions and Ideas \\ Vol 1 No 2 (2022) 207-221 E-ISSN 2809-2058 P-ISSN 2809-2643 \\ DOI: 47467/visa.v1i2.934}

\section{DAFTAR PUSTAKA}

Alam, A., \& Tri Utami, Y. (2021). Unsur Riba dalam Perbedaan Konsep Pinjaman Kredit Antara Rentenir dan Bank Plecit. Al-Kharaj : Jurnal Ekonomi, Keuangan \& Bisnis Syariah, 3(1), 130-141. https://doi.org/10.47467/alkharaj.v3i2.240

Ansori, F., \& Inayah, N. (2021). Prosedur Pemasaran Kredit Kepemilikan Rumah Fasilitas Likuiditas Pembiyaan Perumahan (FLPP). Al-Kharaj : Jurnal Ekonomi, Keuangan \& Bisnis Syariah, 3(3), 358-366. https://doi.org/10.47467/alkharaj.v4i1.391

Ari, Dessanti Putri Sekti. 2013. "Pengaruh Technology Acceptance Model Dan Pengembangannya Dalam Perilaku Menggunakan Core Banking System." Jurnal Keuangan Dan Perbankan 17 (2): 267-78. https://doi.org/https://doi.org/10.26905/jkdp.v17i2.746.

Ghozali, Imam. 2011. Aplikasi Analisis Multivariate Dengan Program IBM SPSS 19. Semarang: Badan Penerbit Universitas Diponegoro.

Jamshidi, D, and A Rezaei. 2012. "Islamic Credit Card Adoption: A Conceptual Framework." Australian Journal of Basic and Applied Sciences 6 (10): 53-60.

Jamshidi, Dariyoush, and Nazimah Hussin. 2012. "A Conceptual Framework for Adoption of Islamic Credit Card in Malaysia." Kuwait Chapter of the Arabian Journal of Business and Management Review 2 (3): 102-10.

Khalid, Junaid, Hasnain Safdar Butt, Muhammad Murtaza, and Usman Khizar. 2013. "Perceived Barriers in the Adoption \& Usage of Credit Cards in Pakistan Banking Industry." International Review of Management and Business Research 2 (1): 10416.

Kusumah, Wijaya. 2009. Mengenal Penelitian Tindakan Kelas. Jakarta: P.T. Indeks.

Mansor, Norudin, and A Che-Mat. 2009. "Islamic Credit Card: Are Demographic Factors a Good Indicator." Asian Social Science 5 (12): 17-26. https://citeseerx.ist.psu.edu.

Mizan, Muhammad Suip Yusri Hasmi. 2014. "Pengaruh Pendapatan Nasabah Terhadap Pengajuan Pembiayaan Pada Bank Pembiayaan Rakyat Syariah Rahmah Hijrah Agung Lhokseumawe Vol 12, No. 2, ISSN 1693-8852." Lhokseumawe: Jurnal Ekonomi dan Bisnis.

Muanas, Arif. 2014. "Perilaku Konsumen.” Yogyakarta: CV Gerbang Media Aksara.

Norman, E. (2020). Syari'ah Card (Kartu Kredit Syariah) Ditinjau dari Maqashid Syari'ah dan Asas Manfaat. Al-Kharaj : Jurnal Ekonomi, Keuangan \& Bisnis Syariah, 2(2), 182-195. https://doi.org/10.47467/alkharaj.v2i2.113

Nurcaya, Ipak Ayu H. 2020. "BNI Bidik Pertumbuhan Transaksi Kartu Kredit Dua Digit.” Bisnis.Com. 2020. https://finansial.bisnis.com/read/20200106/90/1187474/bnibidik-Pertumbuhan-Transaksi-Kartu-Kredit-Dua-Digit. 


\section{VISA: Journal of Visions and Ideas \\ Vol 1 No 2 (2022) 207-221 E-ISSN 2809-2058 P-ISSN 2809-2643 \\ DOI: 47467/visa.v1i2.934}

Prasanti, Erika. 2021. "Pengaruh Pendapatan, Manfaat, Kemudahan Penggunaan, Daya Tarik Promosi, Dan Kepercayaan Terhadap Minat Menggunakan Layanan E-Money (Studi Kasus Pada Mahasiswa Politeknik Harapan Bersama Tegal).” Politeknik Harapan Bersama Tegal.

Rachmawati, Farida. 2017. "Analisis Nasabah Bank BTN Syariah Semarang Terhadap Produk Tabungan Batara IB.” Semarang: Universitas Islam Negeri Walisongo Semarang. https://eprints.walisongo.ac.id/id/eprint/7278.

Rahayu, Siti Kurnia, and Ely Suhayati. 2010. "Perpajakan Teori Dan Teknis Perhitungan.” Yogyakarta: Graha Ilmu.

Salistia, F. (2018). Analisa Faktor Internal Penyebab NPL Kredit Mikro: Studi Kasus PT BPR Wahana Sentra Artha Majalengka. El-Mal: Jurnal Kajian Ekonomi \& Bisnis Islam, 1(1), 49-60. https://doi.org/10.47467/elmal.v1i1.279

Shaleh, Abdul Rahman. 2009. Psikologi Suatu Pengantar Dalam Perspektif Islam. Jakarta: Kencana Prenada Media.

Sopiah, Etta Mamang Sangadji dan. 2013. Perilaku Konsumen. Yogyakarta: Andi.

Sudrajat, Ajat. 2010. Tentang Pendidikan Karakter. Yogyakarta: Paramita.

Ulya, Fika Nurul. 2020. “Pengguna BNI IB Hasanah Card Capai 350.000 Nasabah, Transaksi Liburan Mendominasi." Kompas.Com. 2020. https://money.kompas.com/read/2020/05/20/223800026/pengguna-bni-ibhasanah-card-capai-350000-nasabah-transaksi-liburan. 